\title{
Recent developments in the analysis of Large Wood dynamics in fluvial systems
}

\author{
Stefano Sibilla ${ }^{1}$ (D) Sabrina Meninno ${ }^{2} \cdot$ Ricardo Birjukovs Canelas $^{3}$
}

Received: 13 March 2020 / Revised: 13 March 2020 / Accepted: 20 March 2020 / Published online: 11 April 2020 (c) Springer Nature B.V. 2020

Wood in river plays a significant role in river geomorphology and ecology, by interacting with erosion and sedimentation processes, influencing the nutrients budget and providing physical habitats for a variety of species. However, Large Wood elements (LW, with a trunk diameter $>0.1 \mathrm{~cm}$ and a length $>1 \mathrm{~m}$, as defined by Wohl et al. [38] transported during floods can aggravate the expected drawbacks and augment the overall risk at which the urban areas are exposed [7, 8, 28].

LW may cause obstructions along the channel network, mostly in correspondence of bridges or weirs, where it accumulates, clogging the openings and causing a backwater rise upstream. Hydraulic structures can collapse as a result of the increased loads, and unexpected overflowing can occur at the jammed river cross-sections.

The formation of LW accumulation is thus a key issue in the hydraulic risk assessment and its mechanism, as well its subsequent modelling, is still object of study $[1,10,13,15$, $32,34]$. It is highly affected by the interactions between water, sediments and structures, and it is also influenced by the physical features of LW element and river morphology [30].

Due to the potential implications of LW during floods, different types of practical measures have been developed and employed $[2,5]$ to retain LW upstream of the critical sections (e.g. fins and racks, [26, 33] or to reduce its presence in the river. These measures remain highly linked to the expertise of single practitioners, although recent works have proposed physically based designs of safety structures [25] both in mountain streams and low-land rivers.

The need of giving a quantitative prediction of wood transport during floods throughout the river network has led researchers to investigate water-wood interactions both at a laboratory scale [3, 4, 6, 9] and through numerical models [19, 29]. The motion of floating wood on the water surface has been modelled with different strategies [22, 28, 35], mostly based on Eulerian-Lagrangian approaches able to trace wood motion and rotation.

As an input, the aforementioned models require the volume and distribution of the wood that can be transported by the flood, and these data are affected by high uncertainty and derived through wood budget at basin scale $[16,37]$. In fact, wood entrained in a river can

Stefano Sibilla

stefano.sibilla@unipv.it

1 Department of Civil Engineering and Architecture, University of Pavia, Pavia, Italy

2 CERIS, Instituto Superior Tecnico, Lisbon, Portugal

3 Bentley Systems International Ltd, Lisbon, Portugal 
originate from multiple sources, such as landslides and debris flows in upper basins, and bank erosion in the lower reaches, where the tree roots resistance is a key aspect in the recruitment process of the wood $[18,24,36]$.

Hence, including floating LW in hydraulic risk assessment involves multidisciplinary competencies, from forestry to ecology, from numerical methods to statistical models, which are necessary to estimate wood volumes, predict LW transport and evaluate the probability of entrapment and clogging at hydraulic and retaining structures.

The nine papers collected in this special issue are all derived from researches on the different topics mentioned above which were discussed during Session ST.1 on "Driftwood dynamics in fluvial systems" at the 5th IAHR Europe Congress held in Trento (Italy) on 12-14 June, 2018.

The topics dealt with in the papers range from the development and validation of numerical models to describe the interaction between flow and driftwood [11, 17, 21, 23] to the experimental assessment of the Large Wood blocking at inline structures $[14,20,27$, 31 ], to the evaluation of the stability of riparian vegetation during flood events and its consequent entrainment in the flow [12].

Among the first group of papers, Kimura and Kitazono [17] focus on the applicability of numerical models which couple a fully three-dimensional flow field obtained through a Eulerian flow solver with a two-dimensional Lagrangian model which reproduces the driftwood motion on the water surface (3D-2D coupling). The adopted 2D driftwood model represents the logs as a row of connected spheres, whose motion is calculated through the MPS (Moving Particle Semi-implicit) particle method, taking into account also the collisions between spheres. The driftwood model is applied also to a 2D flow field obtained by depth averaging the 3D one, in order to investigate the influence of the 3D flow features (2D-2D coupling). A Driftwood Richardson number (DRI) is proposed as a non-dimensional index to classify driftwood stacking patterns. One remarkable result is that 2D-2D coupling leads to a higher scattering in the prediction of log positions, while both experiments and 3D-3D coupled numerical simulations show that the logs tend to concentrate in high-velocity flow regions. Experiments in a lab flume also show that driftwood stacking at obstacles occurs as a strongly $3 \mathrm{D}$ process at low values of DRI, and that predictions should be made through a 2D driftwood model only if DRI $>10$, i.e. when driftwood deposition at obstacles occurs mostly two-dimensionally. This limitation also impacts on the capability of 3D-2D models to predict the water level increase due to driftwood drag.

Meninno et al. [21] propose a completely Eulerian model to represent large wood-transport, where advection-diffusion equations are obtained for the space concentration of floating logs and for the probability density function of the orientation of a log in a specific spatial position. In both equations, dispersion due to surface turbulence is modelled through a diffusive term, which in turn depends from diffusion coefficients. The paper focuses on the experimental determination of these diffusion coefficients in uncongested flow conditions: the experiments show that all the coefficients can be estimated as the rate of variance of the $\log$ position/orientation. A preliminary dimensional analysis shows that transversal dispersion tends to increase with the log Froude number, while longitudinal and angular dispersion tend instead to decrease with it.

Persi et al. [23] explore the capability of a Eulerian-Lagrangian model to simulate large wood transport under real-scale conditions. The model, based on the coupling of a Shallow-Water Equations flow solver with a Discrete Element solver for the dynamics of the floating logs, is applied to the simulation of log motion during two high flow events in a 10-day period on the Rienz River, Italy. The results are compared to the field data available from a 3-year long campaign, during which the displacements of more than one hundred 
unbranched logs of various sizes, in part introduced on purpose and in part naturally found along the river reach, were monitored. A good precision can be expected from the simulation at a global level, i.e. when it is aimed at identifying the main areas of deposition of the logs. It proves instead unrealistic to expect an exact tracking of the motion of each wooden $\log$, owing to all the uncertainties related to the modelling. A particular attention, in this sense, should be paid to the correct determination of wood density and to the representation of the interactions of the logs with vegetated banks.

Di Risio and Sammarco [11] examine the effect of floaters on the flow level at a global scale. Based on the drag coefficient of an isolated floater, a physically based modification of the Manning coefficient can be derived in order to compute the free surface profile in the presence of moored floaters or LW accumulated at inline structures. The method is extended to the case of semi-congested and congested transport, through the evaluation of the contact forces among logs and between the logs and the banks. In the latter case, the method requires experimental calibration of parameters accounting for the lateral momentum transfer between logs and the contact probability between logs, in different flow conditions.

In the second group of papers, Furlan et al. [14] focus on the evaluation of the influence of experimental repetitions on the accuracy of LW blocking probability estimations from a statistical analysis derived by laboratory experiments. The results refer to the specific case of the blocking at an ogee crested weir with round nose, as a consequence of semicongested transport of logs (represented in the experiments by artificial plastic stems). The recommendation obtained from the statistical analysis of the results is to repeat each experiment at least 30 times, in order to obtain estimates of the blocking probability with a standard error lower than $10 \%$. The number of repetitions can be decreased if a larger number of stems is employed, because the interaction among the stems lead to smaller standard deviations for an equivalent number of experiment repetitions.

Meninno et al. [20] focus on the interaction between in-stream transported wood and check dams, through an experimental evaluation of the performance of rakes built upstream of slit check dams in clear water conditions. The backwater effect and the trapping efficiency of the wood retaining device are coupled to the different geometries and wood inputs, also including as reference the functioning of the check dam without any rack. The tests show that the rake avoids the direct occlusion of the opening of the check dam, limiting the rise of the water level that would result from the wood accumulation and slit blockage. The performance of the system increases with higher rack inclinations and degrades with the distance from the check dam. In such a case, wood velocities tend to increase, and wood elements slide through the bars of the device. Thanks to the high number of the experimental repetitions, some considerations are drawn on the stochasticity of the clogging process of the check dam, highlighting the variability of the wood entrapment.

Rossi and Armanini [27] analyse the efficiency of different protection structures (slit check dams, either alone or equipped with steel ramps) in mountain steep streams characterized by intense phenomena of driftwood and bed load/debris flow. Several different parameters are defined to evaluate these structural measures, namely the percentage of trapped driftwood, the clogging tie for driftwood and sediment, the driftwood trapping efficiency. A specific experimental campaign shows that simple slit check dams obtain a higher driftwood trapping efficiency only at the price of reducing the clogging time of the solid fraction. Slit check dams equipped with intercepting ramps appear to be more suitable to trap selectively driftwood without reducing their effect on the bed load. However, care should be paid in the number of ramps, which should cover the whole width of the channel, in their spacing, which should be calibrated depending on the wood length, and in their 
inclination, which should be high enough to allow the ramps to intercept the wood within the recirculation zone upstream the check dam.

Schalko et al. [31] discuss the efficiency of different structural measures to reduce the accumulation probability of Large Wood at bridges. After reviewing different structural measures to reduce LW accumulation risk, the results from an extensive experimental campaign focus on two specific measures, i.e. fins installed as un upstream extension of the bridge pier and submerged sills placed along the riverbed at an angle with the flow direction. The accumulation probability is evaluated for both measures, under different flow conditions and geometrical configurations, for uncongested and semi-congested LW transport in a fixed-bed channel. The experiments show that no appreciable reduction of the accumulation probability is obtained from the adoption of fins, while submerged sills appear to be more promising in reducing the accumulation at piers in the tested flow conditions.

Finally, Francalanci et al. [12] investigate the uprooting of riparian vegetation during floods by discussing the joint results of an extensive field survey after an intense flood event and of a conceptual model for tree stability. The field survey was carried out along the Ombrone Grossetano River, Italy, after a 2015 event which resulted in several thousands of wood tons transported to the river mouth. Statistical analysis of the survey results shows that the horizontal distance of the vegetation from the bank, the local bank slope, the tree diameter, the hydraulic conditions around the tree and the relative elevation of the vegetated area are the main variables which control the uprooting process. A conceptual model to evaluate a tree stability parameter as the ratio between the destabilizing moment due to hydraulic drag and the resistant moment due to root-soil interaction is proposed. The application of the conceptual model to the field case (where hydraulic conditions are obtained through a 1D flow model) shows that the detected uprooting conditions can be predicted on average only if the effects of the potential scour around the tree are taken into account.

In conclusion, the whole set of papers in this Issue gives a useful insight of several theoretical, numerical and experimental methods to investigate key aspects of the effects of the entrainment and transport of Large Wood in flood flows, in particular in view of its interaction with inline structures and the resulting impact on hydraulic risk evaluation.

\section{References}

1. Badoux A, Boes RM, Schalko I, Schmocker L, Schwarz M, Steeb N (2016) Large wood research in Swiss watercourses. In: Proceedings of River Flow 2016, pp 2307-2314

2. Bezzola GR, Lange D, Sigg H (2004) Schwemmholzrückhalt in der Schweiz. In: Proceedings of Interpraevent 2004, Riva del Garda, Italia, vol 7, pp 29-40 (in German)

3. Bocchiola D, Rulli MC, Rosso R (2006) Flume experiments on wood entrainment in rivers. Adv Water Resour 29:1182-1195. https://doi.org/10.1016/j.advwatres.2005.09.006

4. Bocchiola D, Rulli MC, Rosso R (2006) Transport of large woody debris in the presence of obstacles. Geomorphology 76:166-178. https://doi.org/10.1016/j.geomorph.2005.08.016

5. Bradley JB, Richards DL, Bahner CD (2005) Debris control structures evaluation and countermeasures. US Dept, Transportation. Tech. Rep. No. FHWA-IF-04-016. Federal Highway Administration, Washington, DC, USA

6. Braudrick CA, Grant GE (2000) When do logs move in rivers? Water Resour Res 36:571-583. https:// doi.org/10.1029/1999WR900290

7. Comiti F, Lucía A, Rickenmann D (2016) Large wood recruitment and transport during large floods: a review. Geomorphology 269:23-39. https://doi.org/10.1016/j.geomorph.2016.06.016

8. Comiti F, Mao L, Preciso E, Picco L, Marchi L, Borga M (2008) Large wood and flash floods: evidence from the 2007 event in the Davča basin (Slovenia). WIT Trans Eng Sci 60:173-182. https://doi. org/10.2495/DEB080181 
9. Crosato A, Rajbhandari N, Comiti F, Cherradi X, Uijttewaal W (2013) Flume experiments on entrainment of large wood in low-land rivers. J Hydraul Res 51:581-588. https://doi. org/10.1080/00221686.2013.796573

10. De Cicco PN, Paris E, Solari L (2015) Flume experiments on bridge clogging by woody debris: the effect of shape of piers. In: Proceedings of 36th IAHR World Congress, The Hague, Netherlands, pp 1-5. https://doi.org/10.13140/RG.2.1.4630.6648

11. Di Risio M, Sammarco P (2019) Effects of floaters on the free surface profiles of river flows. Environ Fluid Mech. https://doi.org/10.1007/s10652-019-09710-z

12. Francalanci S, Paris E, Solari L (2019) On the vulnerability of woody riparian vegetation during flood events. Environ Fluid Mech. https://doi.org/10.1007/s10652-019-09726-5

13. Furlan P, Pfister M, Matos J, Amado C, Schleiss AJ (2017) Experimental repetitions and blockage of large stems at Ogee crested spillways with piers. J Hydraul Res 57:250-262

14. Furlan P, Pfister M, Matos J, Amado C, Schleiss AJ (2019) Statistical accuracy for estimations of large wood blockage in a reservoir environment. Environ Fluid Mech. https://doi.org/10.1007/ s10652-019-09708-7

15. Hartlieb A (2015) Schwemmholz in Fliessgewässern-Gefahren und Lösungsmöglichkeiten. Berichte des Lehrstuhls und der Versuchsanstalt für Wasserbau und Wasserwirtschaft, Technische Uuniversität München, ISBN 978-3-943683-09-7 (in German)

16. Hassan MA, Bird S, Reid D, Hogan D (2016) Simulated wood budgets in two mountain streams. Geomorphology 259:119-133. https://doi.org/10.1016/j.geomorph.2016.02.010

17. Kimura I, Kitazono K (2019) Effects of the driftwood Richardson number and applicability of a 3D-2D model to heavy wood jamming around obstacles. Environ Fluid Mech. https://doi. org/10.1007/s10652-019-09709-6

18. Martin DJ, Benda LE (2001). Patterns of instream wood recruitment and transport at the watershed scale. Trans Am Fish Soc 130, 940-958. https://doi.org/10.1577/15488659(2001)130<0940:POIWRA > 2.0.CO;2

19. Mazzorana B, Comiti F, Volcan C, Scherer C (2011) Determining flood hazard patterns through a combined stochastic-deterministic approach. Nat Hazards 59:301-316. https://doi.org/10.1007/ s11069-011-9755-2

20. Meninno S, Canelas RB, Cardoso AH (2019) Coupling check dams with large wood retention structures in clean water. Environ Fluid Mech. https://doi.org/10.1007/s10652-019-09711-y

21. Meninno S, Persi E, Petaccia G, Sibilla S, Armanini A (2019) An experimental and theoretical analysis of floating wood diffusion coefficients. Environ Fluid Mech. https://doi.org/10.1007/s1065 2-019-09693-x

22. Persi E, Petaccia G, Sibilla S (2016) Large wood transport modelling by a coupled EulerianLagrangian approach. Nat Hazards 91:59-74. https://doi.org/10.1007/s11069-017-2891-6

23. Persi E, Petaccia G, Sibilla S, Lucía A, Andreoli A, Comiti F (2019) Numerical modelling of uncongested wood transport in the Rienz River. Environ Fluid Mech. https://doi.org/10.1007/s1065 2-019-09707-8

24. Picco L, Bertoldi W, Comiti F (2017) Dynamics and ecology of wood in world rivers. Geomorphology 279:1-2. https://doi.org/10.1016/j.geomorph.2016.11.020

25. Piton G, Recking A (2016) Design of sediment traps with open check dams. II: woody debris. J Hydraul Eng 142:1-17. https://doi.org/10.1061/(ASCE)HY.1943-7900.0001049

26. Rimbock A, Strobl T (2002) Loads on rope net constructions for woody debris entrapment in torrents. In: Proceedings of Interpraevent 2002 in the Pacific Rim, Matsumoto, Japan, vol 2, pp 797-807

27. Rossi G, Armanini A (2019) Experimental analysis of devices upholding open check dams from driftwood. Environ Fluid Mech. https://doi.org/10.1007/s10652-019-09714-9

28. Ruiz Villanueva V, Bladé Castellet E, Díez-Herrero A, Bodoque JM, Sánchez-Juny M (2014) Twodimensional modelling of large wood transport during flash floods. Earth Surf Proc Land 39:438449. https://doi.org/10.1002/esp.3456

29. Ruiz-Villanueva V, Piégay H, Gurnell AA, Marston RA, Stoffel M (2016) Recent advances quantifying the large wood dynamics in river basins: New methods and remaining challenges. Rev Geophys 54:611-652. https://doi.org/10.1002/2015RG000514

30. Schalko I, Schmocker L, Weitbrecht V, Boes RM (2018) Backwater rise due to Large Wood accumulations. J Hydraul Eng 144:04018056. https://doi.org/10.1061/(ASCE)HY.1943-7900.0001501

31. Schalko I, Schmocker L, Weitbrecht V, Boes RM (2019) Risk reduction measures of large wood accumulations at bridges. Environ Fluid Mech. https://doi.org/10.1007/s10652-019-09719-4

32. Schmocker L, Hager WH (2011) Probability of drift blockage at bridge decks. J Hydraul Eng 137:470-479. https://doi.org/10.1061/(ASCE)HY.1943-7900.0000319 
33. Schmocker L, Hager WH (2013) Scale modeling of wooden debris accumulation at a debris rack. J Hydraul Eng 139(8):827-836. https://doi.org/10.1061/(ASCE)HY.1943-7900.0000714

34. Schmocker L, Weitbrecht V (2013) Driftwood: risk analysis and engineering measures. J Hydraul Eng 139:683-695. https://doi.org/10.1061/(ASCE)HY.1943-7900.0000728

35. Shrestha BB, Nakagawa H, Kawaike K, Baba Y, Zhang H (2012) Driftwood deposition from debris flows at slit-check dams and fans. Nat Hazards 61:577-602. https://doi.org/10.1007/s1106 9-011-9939-9

36. Steeb N, Rickenmann D, Badoux A, Rickli C, Waldner P (2017) Large wood recruitment processes and transported volumes in Swiss mountain streams during the extreme flood of August 2005. Geomorphology 279:112-127. https://doi.org/10.1016/j.geomorph.2016.10.011

37. Wohl E (2017) Bridging the gaps: an overview of wood across time and space in diverse rivers. Geomorphology 279:3-26. https://doi.org/10.1016/j.geomorph.2016.04.014

38. Wohl E, Cenderelli DA, Dwire KA, Ryan-Burkett SE, Young MK, Fausch KD (2010) Large in-stream wood studies: a call for common metrics. Earth Surf Proc Land 35:618-625. https://doi.org/10.1002/ esp. 1966 